\title{
Human Suicide Risk Study and Treatment: A Mathematical Approach
}

\section{Lu DY** and Lu TR ${ }^{2}$}

${ }^{1}$ School of Life Sciences, Shanghai University, Shanghai 200444, PR China

${ }^{2}$ College of Science, Shanghai University, Shanghai 200444, PR China

\begin{abstract}
Antidepressants can relief human human depressive symptoms-possibly association with human suicide events. The mechanisms of action for these drugs remain to be established. The patho-therapeutic relationships between mental genetics and suicidal risks have also been proposed more recently. To deal with the hot topic of suicide prevention and treatments, mathematical approaches seem revolutionary ideas. Hopefully, suicidal risks and therapeutic outcomes can be improved in the future.
\end{abstract}

Keywords: Human genome human suicide; Mental disorder; Genetic diagnostics; Drug developments; Suicide prevention; Suicide treatments; Molecular target

\section{Introduction}

Human suicide is the causality of a great number of human mortality (2\% human mortality worldwide) [1]; which is a common symptom of human depression worldwide [1-8]. Owing to long term economic depression in recent years; human suicide might still persist among most nations. In order to reduce human suicide; some good examples and paradigms have been speculated and systematical investigated during the past several decades-including the developments of selective serotonin reuptake inhibitors (SSRIs) [1-8].

\section{Causality of Human Suicide}

The causality of human suicides can be diversified; Several major factors are enlisted as; Human mental illness [9]; Past physical or psychiatric traumas [10]; Environmental/economical burden or pressures [11]; Human genetic changes [1,5,6]; Current therapeutics show some positive outcomes in suicidal/mental illness treatments (Table 1) [12].

\section{Genetic or Molecular Approaches}

Like many biomedical factors aforementioned; laboratory facility supports and technical details also determine the quality of suicide study [13-15]. Previously; the severity of drug risks and drug responses are decided by different types of toxicity symptoms. Integration of these two different types of diagnostics (symptom score systems as well as genetic/molecular technology) is a future trend.

\section{Mathematical Study of Human Suicide}

\section{Problem generations}

Given the fact that a lot of inherent/environmental factors can induce human suicide [8-11]; suicide prevention and treatments are very difficult. Mathematical approaches can help to find these relations. In the previous study; we give an equation of their possibilities [14];

\begin{tabular}{|c|c|}
\hline Animal models and studies & Optogenetics GEM \\
\hline Clinical PG studies & $\begin{array}{c}\text { Human metabolic enzymes, such as } \\
\text { CYP2D6 } \\
\text { Drug-active or drug-toxic genes (SNPs) }\end{array}$ \\
\hline $\begin{array}{c}\text { Genome-wide association studies } \\
\text { (GWAS) }\end{array}$ & $\begin{array}{c}\text { More than } 10 \text { genetic allels are discovered } \\
\text { Other biological systems }\end{array}$ \\
\hline
\end{tabular}

Table 1: Brief outlines of current achievements relating to antidepressant therapies.

$$
\mathrm{P}_{\text {total }}=\mathrm{P}_{\text {gene }}+\mathrm{P}_{\text {drug }}+\mathrm{P}_{\text {environment }}
$$

In order to find the overlap of their interactions; we offer a new equation;

$$
\mathrm{X}=f\left(\mathrm{U}_{1} ; \ldots ; \mathrm{U}_{\mathrm{k}}\right)
$$

$\mathrm{X}$; Total suicide rates

$\mathrm{U}$; Individual causality.

Furthermore; it can be calculated in eqn. (3).

$$
\mathrm{T}\left(\mathrm{P}_{1} ; \ldots ; \mathrm{P}_{\mathrm{n}}\right)=\Theta\left(\mathrm{P}_{\mathrm{n}}\right)
$$

Overall; we believe that we can learn more after these computational calculation and statistics [16].

\section{Conclusion}

There is no well-established ideology for suicide causality and treatment now. Several types of diseases; such as mental disorders are possible targets for drug intervention $[1-8,17,18]$. In the future; modern diagnostics for suicide and treatments in clinics must be strengthened and categorized. Increasing mandatory genetic/molecular/image diagnostic trials are required in most advanced countries in the future including mathematical ones.

\section{References}

1. Al Jadid MS (2011) Rehabilitation medicine in the Kingdom of Saudi Arabia Saudi Med J 32: 962-963.

2. Al Hamed JH, Taha AZ, Sabra AA, Bella H (2008) Attention Deficit Hyperactivity Disorder (ADHD) among Male Primary School Children in Dammam, Saudi Arabia: Prevalence and Associated Factors. J Egypt Public Health Assoc 83: 165-182.

3. Amr M, Raddad D, El-Mehesh F, Mahmoud EH, El-Gilany AH (2011) Sex differences in Arab children with Autism spectrum disorders. Res Autism Spectr Disord 5: 1343-1350.

4. Matson JL, Rieske RD, Williams LW (2013) The relationship between autism spectrum disorders and attention-deficit/hyperactivity disorder: an overview. Res Dev Disabi 34: 2475-2484.

*Corresponding author: Lu DY, Associate Professor, School of Life Sciences, Shanghai University, China, E-mail: ludayong@sh163.net

Received April 22, 2018; Accepted May 10, 2018; Published May 18, 2018

Citation: Lu DY, Lu TR (2018) Human Suicide Risk Study and Treatment: A Mathematical Approach. J Ment Disord Treat 4: 161. doi:10.4172/2471271X.1000161

Copyright: (c) 2018 Lu DY, et al. This is an open-access article distributed under the terms of the Creative Commons Attribution License, which permits unrestricted use, distribution, and reproduction in any medium, provided the original author and source are credited. 
Citation: Lu DY, Lu TR (2018) Human Suicide Risk Study and Treatment: A Mathematical Approach. J Ment Disord Treat 4: 161. doi:10.4172/2471271X.1000161

Page 2 of 2

5. Sinzig J, Walter D, Doepfner M (2009) Attention deficit/hyperactivity disorder in children and adolescents with autism spectrum disorder: symptom or syndrome? J Atten Disord 13: 117-126.
6. Salhia HO, Al-nasser LA, Taher LS, Al-khathaami AM (2014) Systemic review of the of autism in Arab Gulf countries, Neurosciences Riyadh 19: 291-296. 